\title{
Bibliography of UC ANR research on the Healthy Families and Communities Strategic Initiative priorities
}

\section{A Partial Bibliography}

Tote: The following compilation 1 includes peer-reviewed academic articles published since 2009. Authored by UC ANR academics, they address one or more of the three priorities of the HFC Strategic Initiative: healthy living for obesity prevention, youth science literacy, and positive youth development. The list is just a starting point; more research studies are being published all the time. The research informs UC Cooperative Extension teaching and extension programs across California communities.

Alston, J. M., Mullally, C.C., Sumner, D.A., Townsend, M., \& Vosti, S.A. (2009). Likely Effects on Obesity from Proposed Changes to the U.S. Food Stamp Program. Food Policy 34(2009), 176-184. doi: 10.1016/j.foodpol.2008.10.013

Bachman, J.G., O'Malley, P.M., Freedman-Doan, P., Trzesniewski, K.H., \& Donnellan, M.B. (2011). Adolescent self-esteem: Differences by race/ethnicity, gender, and age. Self and Identity, 10(4), 445-473.

Banna, J., \& Townsend, M.S. (2011). Assessing factorial and convergent validity and reliability of a food behavior checklist for Spanish-speaking participants in USDA nutrition education programs. Public Health Nutrition, 14(7), 1165-1176.

Banna, J.C., Kaiser, L.L., Drake, C., \& Townsend, M.S. (2012). Acculturation, physical activity and television viewing in Hispanic women: findings from the 2005 California Women's Health Survey. Public health nutrition, 15(2), 198-207.

Banna, J.C., Keim, N.L., \& Townsend, M.S. (2011). Assessing face validity of a physical activity questionnaire for Spanish-speaking women in California. Journal of Extension, 49, 5.

Banna, J.C., Vera Becerra, L.E., Kaiser, L.L., \& Townsend, M.S. (2010). Using qualitative methods to improve questionnaires for Spanish speakers: assessing face validity of a food behavior checklist. Journal of the American Dietetic Association, 110(1), 80.

Bird, M., Borba, J., Horowitz, M., Coutellier, C., \& Dixon, T. (2010). Counselor-In-Training: Encouraging Youth Development Outcomes at Camp. A Guide Book. American Camp Association.

Bird, M., and Subramaniam, A. (2011). Teens as Teachers Enhance Environmental Education and Personal Skills Through Service Learning. University of California: Davis, CA.

Brent Donnellan, M., Kenny, D.A., Trzesniewski, K.H., Lucas, R.E., \& Conger, R.D. (2012). Using Trait-State Models to Evaluate the Longitudinal Consistency of Global Self-Esteem From Adolescence to Adulthood. Journal of research in personality.
Brown, S., \& Getz, C. (2011). Farmword Food Insecurity and the Production of Hunger in California. In A.H. Alkon \& J. Agyeman (Eds.), Cultivating Food Justice: Race, Class, and Sustainability: MIT Press.

Campbell, D., \& Erbstein, N. (2012). Engaging youth in community change: three key implementation principles. Community Development, 43(1), 63-79.

Carlos, R.M., Borba, J., Heck, K.E., Nathaniel, K.C., \& Sousa, C.M. (2009). Survey explores teen driving behavior in Central Valley, Los Angeles high schools. California Agriculture, 63(4), 208-214. doi: 10.3733/ ca.v063n04p208

Chaidez, V., \& Kaiser, L.L. (2011). Validation of an instrument to assess toddler feeding practices of Latino mothers. Appetite, 57(1), 229-236.

Chaidez, V., Townsend, M., \& Kaiser, L.L. (2011). Toddler-feeding practices among Mexican American mothers. A qualitative study. Appetite, 56(3), 629-632.

Cortz, S., Wooten Swanson, P., Roche, B., Peterson, S., Johns, M., Go, C., Varcoe, K., \& UCCE Money Talks Workgroup. (rev. 2012). Savings Made Simple. Leader's Guide. University of California Cooperative Extension, ANR Pub. 8269

Crawford, P.B., Gosliner, W., \& Kayman, H. (2011). The Ethical Basis for Promoting Nutritional Health in Public Schools in the United States. Preventing Chronic Disease, 8(5).

Dogan, S.J., Stockdale, G.D., Widaman, K.F., \& Conger, R.D. (2012). Developmental relations and patterns of change between alcohol use and number of sexual partners from adolescence through adulthood. Developmental Psychology, 46(6), 1747-1759. doi: 10.1037/a0019655

Donnellan, M.B., \& Trzesniewski, K.H. (2009). How Should We Study Generational 'Changes' - Or Should We? A Critical Examination of the Evidence for 'Generation Me.' Social and Personality Psychology Compass, 3(5), 775-784.

Donnellan, M.B., \& Trzesniewski, K.H. (2010). Teaching and Learning Guide for: How Should We Study Generational 'Changes'-Or Should We? A Critical Examination of the Evidence for 'Generation Me'. Social and Personality Psychology Compass, 4(1), 77-81.

Enfield, R., \& Owens, P. E. (2009). Building and Sustaining Community-Based Youth Development Collaboratives. Community Development, 40(4), 381-397. doi: 10.1080/15575330903304875

Farfan-Ramirez, L. (2010). From the Garden to the Classroom Connecting the Dots Training Manual. Davis: University of California.

Farfan-Ramirez, L. (2011). Grow It and Eat It Fresh: Farm to School Curriculum 4th Grade Level. Davis: University of California.

Farfan-Ramirez, L., \& Gong, E. (2011). Evaluation Results of Multi-Level Nutrition Education through SNAP-Ed. Journal of Nutrition Education, 43(S42), 162165.

Farfan-Ramirez, L., \& Gong, E. (2011). Grow lt and Eat It Fresh: Classroom Workbooks Grades 1 through 6. Davis: University of California.
Ganthavorn, C. (2010). Marketing Produce to American Consumers. ISHS Acta Horticulturae 875: Southeast Asia Symposium on Quality and Safety of Fresh and Fresh-Cut Produce.

Gosliner, W.A., James, P., Yancey, A.K., Ritchie, L., Studer, N., \& Crawford, P.B. (2010). Impact of a Worksite Wellness Program on the Nutrition and Physical Activity Environment of Child Care Centers. American Journal of Health Promotion, 24(3), 186-189. doi: 10.4278/ajhp.08022719

Hayden-Smith, R. (accepted for publication). Sowing the Seeds of Victory: National Gardening Programs in World War I and Why They Matter Today (working title) McFarland.

Hazzard, E.L., Moreno, E., Beall, D.L., \& ZidenbergCherr, S. (2011). An evaluation of the California Instructional School Garden Program. Public health nutrition, 15(2), 285.

Hazzard, E.L., Moreno, E., Beall, D.L., \& ZidenbergCherr, S. (2011). Best practices models for implementing, sustaining, and using instructional school gardens in California. Journal of Nutrition Education and Behavior, 43(5), 409-413.

Hazzard, E.L., Moreno, E., Beall, D.L., \& ZidenbergCherr, S. (2012). Factors Contributing to a School's Decision to Apply for the California Instructional School Garden Program. Journal of Nutrition Education and Behavior.

Heck, K.E., Carlos, R.M., Barnett, C., \& Smith, M.H. (2012). 4-H Participation and Science Interest in Youth Journal of Extension, 50(2).

Heck, K.E., \& Nathaniel, K.C. Driving Among Urban, Suburban and Rural Youth in California. Youth Development, 11.

Heck, K.E., Sousa, C., Hanna, C.L., \& Nathaniel, K. (2008). Unlicensed driving among California high school seniors. Californian J Health Promot., 6, 36-48.

Johns, M., \& Townsend, M.S. (2010). Client-driven tools: Improving evaluation for low-literate adults and teens while capturing better outcome. Forum for Family and Consumer Issues, 15(3).

Joy, A.B., \& Hudes, M. (2010). High risk for depression among low income women raises awareness about treatment options. California Agriculture, 64(1), 22-25. Junge, S.K., Manglallan, S., Reilly, J., \& Killian, E. (2010). Tools of the Trade II: Inspiring young minds to be SET ready for life: University of California.

Kaiser, L., Martin, A., \& Steinberg, F. (2010). Research and outreach can lessen the overall burden of diabetes in farmworkers. California Agriculture, 64(1), 17-21. doi: 10.3733/ca.v064n01p17

Kaiser, L.L., Lamp, C., Ganthavorn, C., Farfan-Ramirez, L., McMurdo, T.J., Cantwell, M., \& Hardesty, S.D. (2012). UC Cooperative Extension explores a farm-to-WIC program. California Agriculture, 66(1), 15-19. doi: 10.3733/ca.v066n01p15

Kaiser, L.L., Martin, A.C., Blackburn, M.L., Metz, D.L., Smith, D., Donohue, S.S., Lexion, C., \& Steinberg, FM. (2009). Take Care of Your Health! An Extension Program to Prevent Diabetes. Journal of Extension, 47(4). 
Kaiser, L.L., Schneider, C., Mendoza, C., George, G., Neelon, M., Roche, B., \& Ginsburg, D. (2012). Development and Use of an Evaluation Tool for Taste-Testing Activities by School-Aged Children. Journal of the Academy of Nutrition and Dietetics.

Kuyper, E.M., Smith, D., \& Kaiser, L.L. (2009). Does Food Insecurity Influence Child Feeding Practices? Journal of Hunger \& Environmental Nutrition, 4(2), 147-157.

Madsen, K.A., McCulloch, C.E., \& Crawford, P.B. (2009). Parent Modeling: Perceptions of Parents' Physical Activity Predict Girls'Activity throughout Adolescence. The Journal of Pediatrics, 154(2), 278-283.e272. doi: 10.1016/j.jpeds.2008.07.044

Madsen, K.A., Weedn, A.E., \& Crawford, P.B. (2010). Disparities in Peaks, Plateaus, and Declines in Prevalence of High BMI Among Adolescents. Pediatrics, 126(3), 434-442. doi: 10.1542/peds.2009-3411

Madsen, K.A., Gosliner, W., Woodward-Lopez, G., \& Crawford P.B. (2009). Physical activity opportunities associated with fitness and weight status among adolescents in low-income communities. Archives of Pediatrics \& Adolescent Medicine, 163(11), 1014-1021. doi: 10.1001/archpediatrics.2009.181

Mahacek, R., \& Worker, S. (2011). Extending science education with engineering and technology: Junk drawer robotics curriculum. . In K. Heck A. Subramaniam, R. Carlos, \& S. Junge (Ed.), Advances in youth development: Research and evaluation from the University of California Cooperative Extension 2001-2010 (pp. 46-57). Davis, CA: University of California Agriculture and Natural Resources.

Martin, M.J., Conger, R.D., Schofield, T.J., Dogan, S.J., Widaman, K.F., Donnellan, M.B., \& Neppl, T.K. (2010). Evaluation of the interactionist model of socioeconomic status and problem behavior: A developmental cascade across generations. [10.1017/ S0954579410000374]. Development and Psychopathology, 22(Special Issue 03), 695-713.

Matthiessen, T., Horowitz, M., Neelon, M., Smith, D., \& Kaiser, L. Insights from an Evaluation of a Healthy Living Project. Youth Development, 61.

Matthiessen, T.B., Steinberg, F.M., \& Kaiser, L.L. (2011). Convergent validity of a digital image-based food record to assess food group intake in youth. Journal of the American Dietetic Association, 111(5), 756-761.

McMurdo, T., Lippitt, N., Smith, D., Horowitz, M., Spezzano, T., \& Neelon, M. (2012). Healthalicious: Nutrition \& Cooking Curriculum for upper elementary $4-\mathrm{H}$ youth UCPublications.

Moncloa, F., Schmitt-McQuitty, L., Go, C., Nathaniel, K.C., \& Truong, T.A.N. A Safe Place to Learn and Grow: Fostering Youth Social Skills in Afterschool Programs. Youth Development, 27.

Moncloa, F., Wilkinson-Lee, A.M., \& Russell, S.T. (2010). Cuídate Sin Pena: Mexican Mother-Adolescent Sexuality Communication. Journal of Ethnic \& Cultural Diversity in Social Work, 19(3), 217-234.

Ontai, L., Ritchie, L., Williams, S.T., Young, T., \& Townsend, M.S. (2009). Guiding family-based obesity prevention efforts in low-income children in the United States: Part 1-What determinants do we target. International Journal Child Adolescent Health, 2(1), 19-30.
Ontai, L., Ritchie, L., Williams, S.T., Young, T., \& Townsend, M.S. (2009). Guiding family-based obesity prevention efforts in low-income children in the United States: Part 2 - What behaviors do we ensure? International Journal Child Adolescent Health, 2(1), 31-48.

Ontai, L., Ritchie, L., Williams, S.T., Young, T., \& Townsend, M.S. (2009). Guiding family-based obesity prevention efforts in low-income children in the United States: Part 1-What determinants do we target Child and Adolescent Health Yearbook 2009 (pp. 25-40). New York: Nova Science Publishers, Inc.

Ontai, L., Ritchie, L., Williams, S.T., Young, T., \& Townsend, M.S. (2009). Guiding family-based obesity prevention efforts in low-income children in the United States: Part 2 - What behaviors do we measure? Child and Adolescent Health Yearbook 2009 (pp. 41-60). New York: Nova Science Publishers, Inc.

Ontai, L., Grajales-Hall, M., Horowitz, M., Junge, S., Lamp, C., Manglallan, S., Smith, D., \& Spezzano, T. (2012). Healthy Happy Families Mini-series Curriculum UC Publications.

Ontai, L.L. Development of children's early eating behaviors: Understanding parenting and child factors. Parenting, 8(18), 19.

Orth, U., Robins, R.W., Trzesniewski, K.H., Maes, J., \& Schmitt, M. (2009). Low self-esteem is a risk factor for depressive symptoms from young adulthood to old age. Journal of Abnormal Psychology; Journal of Abnormal Psychology, 118(3), 472.

Orth, U., Trzesniewski, K.H., \& Robins, R.W. (2010). Selfesteem development from young adulthood to old age: A cohort-sequential longitudinal study. Journal of personality and social psychology, 98(4), 645.

Peterson, S., Varcoe, K., Nathaniel, K., Wooten Swanson, P., Go, C., Johns, M., Roche, B., Cortz, S., \& UCCE Money Talks Workgroup. (2010). Job Personality. Leader's Guide. University of California Cooperative Extension, ANR Pub. 8414.

Peterson, S., Roche, B., Cortz, S., Johns, M., Go, C., Nathaniel, K., Varcoe, K., \& UCCE Money Talks Workgroup. (rev. 2011). Hunger Attack! Feed Your Appetite-Protect Your Wallet. Leader's Guide. University of California Cooperative Extension, ANR Pub. FS8274.

Peterson, S., Roche, B., Johns, M., Go, C., Nathaniel, K., Varcoe, K., \& UCCE Money Talks Workgroup. (rev. 2011). Hunger Attack! Feed Your Appetite-Protect Your Wallet. Teen Guide. University of California Cooperative Extension, ANR Pub. 8275

Peterson, S., Wooten Swanson, P., Roche, B., Johns, M., Go, C., Nathaniel, K., Varcoe, K., Cortz, S., \& UCCE Money Talks Workgroup. (rev. 2011). Savings Made Simple. Teen Guide. University of California Cooperative Extension, ANR Pub. 8270.

Reicks, M., Degeneffe, D., Ghosh, K., Bruhn, C., Goodell, L.S., Gunther, C., Auld, G., Ballejos, M., Boushey, C., Cluskey, M. Misner, S., Olson, B., Wong S., \& Zaghloul, S. (2012). Parent calcium-rich-food practices/ perceptions are associated with calcium intake among parents and their early adolescent children. Public Health Nutrition, 15(2), 331-340. doi: 10.1017/ S1368980011001133

Ritchie, L.D., Martin, A.C., Rodriguez, L., Johns, M., Lamp, C., Wang, M.C., \& Crawford, P.B. (2009). Teaching Kids What to Eat Where They Eat: Developing and Pilot Testing the Nutrition Education in Foodservice Toolkit. Journal of Extension, 47(4).
Ritchie, L.D., Whaley, S.E., Spector, P., Gomez, J., \& Crawford, P.B. (2010). Favorable Impact of Nutrition Education on California WIC Families. Journal of Nutrition Education and Behavior, 42(3, Supplement), S2S10. doi: 10.1016/j.jneb.2010.02.014

Robins, R.W., Trzesniewski, K.H., \& Donnellan, M.B. (2012). A Brief Primer on Self-Esteem. Prevention Researcher, 19(2), 3-7.

Roche, B., Nathaniel, K., Johns, M., Varcoe, K., Swanson, P. W., Peterson, S., Go, C., Cortz, S., \& UCCE Money Talks Workgroup. (2010). Job Search. Leader's Guide. University of California Cooperative Extension, ANR Pub. 8416.

Samuels, S.E., Craypo, L., Boyle, M., Crawford, P.B., Yancey, A., \& Flores, G. (2010). The California Endowment's Healthy Eating, Active Communities Program: A Midpoint Review. American Journal of Public Health, 100(11), 2114-2123. doi: 10.2105/ajph.2010.192781

Samuels, S.E., Lawrence Bullock, S., Woodward-Lopez, G., Clark, S.E., Kao, J., Craypo, L., Barry, J., \& Crawford, P.B. (2009). To What Extent Have High Schools in California Been Able to Implement State-Mandated Nutrition Standards? Journal of Adolescent Health, 45(3, Supplement), S38-S44. doi: 10.1016/j.jadohealth.2009.03.015

Sanchez-Vaznaugh, E.V., Sánchez, B.N., Baek, J., \& Crawford, P.B. (2010). Competitive'Food And Beverage Policies: Are They Influencing Childhood Overweight Trends. Health Affairs, 29(3), 436-446. doi: 10.1377/hlthaff.2009.0745

Schaefer, S., Salazar, M., Bruhn, C., Saviano, D., Boushey, C., \& Van Loan, M. (2009). Influence of Race, Acculturation, and Socioeconomic Status on Tendency Toward Overweight in Asian-American and Mexican-American Early Adolescent Females. Journal of Immigrant and Minority Health, 11(3), 188-197. doi: 10.1007/s10903-008-9150-6

Scherr, R.E., Reed, H., Briggs, M., \& Zidenberg-Cherr, S. (2011). Development and Evaluation of Nutrition Education Competencies and a Competency-Based Resource Guide for Preschool-Aged Children. Journal of Child Nutrition \& Management, 35(2), n2.

Schmitt-McQuitty, L., \& Smith, M.H. Moving Beyond the Demonstration Model: The Importance of Experiential Learning in the 4-H Youth Development Program. Youth Development, 83.

Schmitt-McQuitty, L., Smith, M.H., \& Chin Young, J. (2011). Preparing Volunteers to Meet the Developmental Needs of Youth Audiences. Journal of Extension, 49(1), n1.

Serrano, E., McFerren, M., Lambur, M., Ellerbock, M., Hosig, K., Franz, N., Townsend, M., Baker, S., Muennig, P. \& Davis, G. (2011). Cost-Effectiveness Model for Youth EFNEP Programs: What Do We Measure and How Do We Do It? Journal of Nutrition Education and Behavior, 43(4), 295-302.

Shilts, M., Martin, A., \& Townsend, M. (2009). Dose: Comparison of 6 and 12 Nutrition and Physical Activity Sessions Targeting Middle School Adolescents. Journal of Youth Development: Bridging Research and Practice, 4(4).

Shilts, M.K., Horowitz, M., \& Townsend, M.S. (2009). Guided goal setting: effectiveness in a dietary and physical activity intervention with low-income adolescents. International Journal of Adolescent Medicine and Health, 21(1), 111-122. 
Shilts, M.K., Lamp, C., Horowitz, M., \& Townsend, M.S. (2009). Pilot Study: EatFit Impacts Sixth Graders'Academic Performance on Achievement of Mathematics and English Education Standards. Journal of Nutrition Education and Behavior, 41(2), 127-131. doi: 10.1016/j. jneb.2008.05.007

Shilts, M.K.; Smith, D.; Ontai, L.; Townsend, M.. (2008), Evidence to Support the Use of the Retrospective Pretest method to Measure Dietary and Physical Activity Behavior and Self-Efficacy in Adolescents. Journal of Youth Development, 3(1).

Subramaniam, A., Dasher, H.S., \& Chin Young, J. (2011) County Clustering for the California 4-H Youth Development Program: Impacts and Lessons Learned Journal of Extension, 50(2).

Subramaniam, A., \& Moncloa, F. (2010). Young people's perspectives on creating a participation friendly culture. Children, Youth and Environments, 20(2), 25-45.

Townsend, M.S., Melgar-Quinonez, H., Hudes, M. \& Crawford, P. (2009). How Well Do Parents in the United States Report Heights and Weights for Children? International Public Health Journal, 1(1), 41-49.

Townsend, M.S., Melgar-Quinonez, H., Hudes, M., \& Crawford, P. (2009). How Well Do Parents in the United States Report Heights and Weights for Children? In J. Merrick (Ed.), Public Health Yearbook 2009 (pp. 45-56). New York: Nova Science Publishers, Inc.

Townsend, M.S. (2010). Where is the science? What will it take to show that nutrient profiling systems work? The American journal of clinical nutrition, 91(4), 1109S-1115S.

Townsend, M.S., Aaron, G.J., Monsivais, P., Keim, N.L., \& Drewnowski, A. (2009). Less-energy-dense diets of low-income women in California are associated with higher energy-adjusted diet costs. The American journal of clinical nutrition, 89(4), 1220-1226.

Townsend, M.S., Keim, N., Kuyper, E., Smith, D., Lamp, C., Martin, A., Metz, D., \& Kaiser, L.L. (2009). Mothers' perceptions of portion size: Are they fueling the child obesity epidemic? Forum for Family and Consumer Issues, 14(2).

Tracy, J.L., Cheng, J.T., Robins, R.W., \& Trzesniewski, K.H. (2009). Authentic and hubristic pride: The affective core of self-esteem and narcissism. Self and Identity, 8(2-3), 196-213.

Trzesniewski, K.H., \& Donnellan, M.B. (2009). Reevaluating the Evidence for Increasingly Positive Self-Views Among High School Students More Evidence for Consistency Across Generations (1976-2006). Psychological Science, 20(7), 920-922.

Trzesniewski, K.H., \& Donnellan, M.B. (2010). Rethinking "Generation Me" a study of cohort effects from 1976-2006. Perspectives on Psychological Science, 5(1), 58-75

TrzesniewsKi, K.H., Kinal, M., \& Donnellan, M.B. (2010). Self-enhancement and self-protection in a developmental context. The handbook of self-enhancement and self-protection, 341-357.

Varcoe, K., Go, C., Johns, M., Peterson, S., Nathaniel, K., Roche, B., Wooten Swanson, P., Cortz, S., \& UCCE Money Talks Workgroup. (2010). Making My Own Job. Leader's Guide. University of California Cooperative Extension, ANR Pub. 8420 (Vol. 8420).
Varcoe, K.P., Peterson, S.S., Wooten Swanson, P., \& Johns, M.C. (2010). What Do Teens Want to Know About Money_A Comparison of 1998 and 2008 Family and Consumer Sciences Research Journal, 38(4), 360-371. doi: 10.1111/j.1552-3934.2010.00032.x

Wassenberg, K., Peterson, S., Varcoe, K., Wooten Swanson, P., Nathaniel, K., Johns, M., Go, C., Roche, B., \& UCCE Money Talks Workgroup. (2009). Privacy, Please! Teen Guide. University of California Cooperative Extension, ANR Pub. 8405

Wassenberg, K., Nathaniel, K., Varcoe, K., Roche, B., Johns, M., Go, C., Wooten Swanson, P., Peterson, S., \& UCCE Money Talks Workgroup. (2010). Job Personality. Teen Guide. University of California Cooperative Extension, ANR Pub. 8415.

Wassenberg, K., Nathaniel, K., Varcoe, K., Roche, B. Johns, M., Go, C., Wooten Swanson, P., Peterson, S., \& UCCE Money Talks Workgroup. (2010). Job Search. Teen Guide. University of California Cooperative Extension, ANR Pub. 8417.

Wassenberg, K., Nathaniel, K., Varcoe, K., Roche, B., Johns, M., Go, C., Wooten Swanson, P., Peterson, S., \& UCCE Money Talks Workgroup. (2010). On the Job. Teen Guide. University of California Cooperative Extension, ANR Pub. 8419

Wassenberg, K., Nathaniel, K., Varcoe, K., Roche, B., Johns, M., Go, C., Wooten Swanson, P., Peterson, S. \& UCCE Money Talks Workgroup. (2010). Making My Own Job. Teen Guide. University of California Cooperative Extension, ANR Pub. 8421.

Woodward-Lopez, G., Gosliner, W., Samuels, S.E., Craypo, L., Kao, J., \& Crawford, P.B. (2010). Lessons Learned from Evaluations of California's Statewide School Nutrition Standards. American Journal of Public Health, 100(11), 2137-2145.

Wooten Swanson, P., Johns, M., Nathaniel, K., Go, C., Roche, B., Peterson, S., Varcoe, K., \& UCCE Money Talks Workgroup. (2009). Privacy, Please! Leader's Guide. University of California Cooperative Extension, ANR Pub. 8404 (Vol. 8404).

Wooten Swanson, P., Roche, B., Varcoe, K., Peterson S., Nathaniel, K., Johns, M., Go, C., Cortz, S., \& UCCE Money Talks Workgroup. (2010). On the Job. Leader's Guide. University of California Cooperative Extension, ANR Pub. 8418.

Yeager, D.S., Trzesniewski, K., \& Dweck, C.S. (2012). An implicit theories of personality intervention reduces adolescent aggression in response to victimization and exclusion. Child Development.

Yeager, D.S., Trzesniewski, K.H., Tirri, K., Nokelainen, P., \& Dweck, C.S. (2011). Adolescents'implicit theories predict desire for vengeance after peer conflicts: Correlational and experimental evidence. Developmental psychology, 47(4), 1090

Young, T., Barrett, G., Martin, A., Metz, D., Kaiser, L., \& Steinberg, F. (2011). Goal Setting: A Strategy for Reducing Health Disparities. Journal of Extension, 49(2). 